\title{
Network organizations: the structural arrangement behind new organizational forms
}

\author{
José Luis Alvarez \\ Organizational Behavior, IESE, University of Navarra, Barcelona \\ M. Anton Ferreira* \\ Graduate School of Business Leadership, University of South Africa, P.O. Box 392, Pretoria, 0001 Republic of South Africa \\ Received June 1995

\begin{abstract}
This article elaborates the main meanings of the concept 'network organization' and the underlying structural arrangement behind most of the new organizational forms and the main alternative to the still dominant bureaucratic organizational structure. The concept is applied to four levels of analysis: macro economic and business systems; inter-organizational collaborative arrangements; intra-organizational structures; and informal intra-organizational social systems. Through this taxonomy, an attempt is made to disentangle the different meanings of the concept 'network organization'. Throughout, we seek to highlight the main variables that managers should take into account when making decisions and conducting operations in networks. The article commences with a brief historical overview of the evolution of organizational forms and the driving forces behind current development in the field.
\end{abstract}

Hierdie artikel ontwikkel die belangrikste betekenisse wat aan die konsep 'netwerkorganisasie' geheg word en die implikasies daarvan vir die strukturering en bestuur van organisasies. Ons argumenteer dat die netwerkorganisasie die onderliggende strukturele vorm agter die meeste van die nuwe organisatoriese strukture is, asook die belangrikste alternatief vir die steeds dominante burokratiese organisasievorm. Die konsep word op vier vlakke van analise toegepas: makro ekonomiesc en bedryfstelsels; interorganisatoriese samewerkingstrukture; intra-organisatoriese vorms; en informele intraorganisatoriese sosiale stelsels. Met hierdie taksonomie word 'n poging aangewend om die verskillende betekenisse van die konsep 'netwerkorganisasie' te isoleer. Deurgaans poog ons om die belangrike veranderlikes wat bestuurders in aanmerking moet neem tydens die neem van besluite en die bestuur van aktiwiteite in netwerke, uit te lig. Die artikel begin met 'n bondige historiese oorsig van die evolusie van organisasievorms en die dryfkragte agter die huidige ontwikkelings in die veld.

*Author to whom correspondence should be addressed

\section{Introduction}

Dramatic changes in the nature of competition and increasing demands for new products and services have forced managers all over the world to radically rethink their traditional ways of structuring, managing and governing firms as social arrangements of collective action for economic goals. Increasingly the response has been to flatten organizational structures, to break down the internal barriers between functional areas, and to form linkages or alliances with other organizations. This has led to a proliferation of new organizational forms, the prevalence of which a quick reading of business magazines (see for example Business Week, December 20, 1993), management books and academic journals would easily reveal.

In this article we argue that the network organization is the underlying structural arrangement behind most of the new organizational alternatives. It is proposed as the basic metaphor for all these new ways of organizing and as the main alternative to the still dominant bureaucratic organizational form. However, the notion of 'network' has become ubiquitous and over-applied. It is a concept that cuts across academic disciplines: it is prevalent in organization theory (Nohria \& Eccles, 1992), central in modern social theory (White, 1992), and at the core of new perspectives on economic competition (Burt, 1992). As Nohria (1992: 3) states: 'This indiscriminate proliferation of the network concept threatens to relegate it to the status of evocative metaphor, applied so loosely that it ceases to mean anything'.

The purpose of this article is to elaborate the main meanings of the concept of network organization and its implica- ions for the structuring and governance of corporations. The concept is applied to four levels of analysis: economic and business systems, inter-organizational arrangements, intraorganizational structures, and informal intra-organizational social systems. These levels provide a useful taxonomy for distinguishing between the phenomena associated with the concept 'network' and for appreciating their dynamics.

In addition, the article highlights the main variables that organizational actors should take into account when making decisions and conducting operations in networks. This is especially relevant since the emerging new organizational forms demand significant adjustments in the constituents of the managerial task, and a transformation of the professional identity, skills, knowledge, behaviour, and value systems of executives (Roure, Alvarez, García-Pont \& Nueno, 1993).

The above is preceded by a brief historical overview of the evolution of organizational forms and the driving forces behind current developments in the field. We believe that the article will be of interest not only to scholars unfamiliar with network phenomena, but also to managers and consultants who need to get acquainted with the network organization and its determining variables in order to operate efficiently in a changing environment characterized by loosely structured social systems.

\section{Background}

Organization structure is generally associated with the two tasks of differentiation (division of labour) and integration (co-ordination). In the literature on organization theory, these concepts date back to the beginning of the century and can be 
found in the works of Taylor (1911), Fayol (1916) and Barnard (1938). However, it was Lawrence \& Lorsch (1967) who made the clear distinction between them and who first highlighted the need for an alignment of organization structure with the environment of the organization. Building on the work of Burns \& Stalker (1961), who distinguish between mechanistic structures for stable environments and organic structures for turbulent environments, Lawrence \& Lorsch argue that organization structure is contingent on the environment. In other words, there is no one best way to organize. The structure of an effective organization has to match the demands of its environment. These demands will determine the nature and degree of differentiation and the required mechanisms for integration.

Subsequently, the notion of 'fit' between organization structure and environmental demands has been expanded to include other organizational elements such as management planning and control processes, information systems, performance measurement systems and reward systems (Galbraith, 1987). In essence, this 'fit' or 'alignment' model is reactive and ecological. Organizations have to fit their environments if they are to survive (Hannan \& Freeman, 1989).

Historically, the basis for differentiation has been organizational functions such as production, marketing, finance and accounting. However, in response to diverse customer demands, excess capacity and the need for growth, many large organizations started to diversify and adopt what became known as the divisional organization structure, where differentiation is based on product lines, customer groupings and/or geographic regions (Chandler, 1962). Subsequently, the matrix structure emerged during the late 60 s which, in an attempt to obtain the best of both worlds (functional and divisional), allowed for the negotiated shared utilization of assets within a dual authority, responsibility and reporting framework (Davis \& Lawrence, 1977). Finally, during the high growth 70 s, many organizations chose to grow through mergers and acquisitions, often unrelated to their main lines of business, which led to the holding company structure with first-level differentiation on the basis of semi-autonomous companies.

In all the above structural forms, integration has been achieved mainly by means of hierarchy. That is, vertically structured authority, communication and reporting lines, rules and procedures, according to the Weberian model of bureaucracy. Although the Weberian bureaucracy is still the dominant organizational form, various new approaches have surfaced since the early 1980 s in response to fundamental changes in the general business environment. The forces that have spearheaded these developments are considered in the following section.

\section{Driving forces of structural change}

Towards the end of the 1970s, the general business sentiment started to turn against the holding company type structure characterized by unrelated diversification. Various factors played a role in fostering this change. Firstly, the oil crises and the internationalization of markets coupled with the emergence of fierce competition from the East, caused companies in the West to take a new look at their cost structures and the requirements for cost-effectiveness and productivity. Secondly, many conglomerates started to run into trouble due to their inability to manage and integrate their diverse businesses. Although not conclusive, some empirical studies found that companies following related diversification strategies outperformed those who diversified into markets unrelated to their main lines of business (Rumelt, 1974). Further impetus to this idea was provided by Peters \& Waterman (1982) who found that excellent companies stayed close to their customers and that they 'stuck to their own knitting'. The result was that 'smallness' became 'beautiful' again and that companies started to concentrate on those things that they were really good at.

The 1980s saw a further escalation and marked intensification in the demands of the business environment. In an attempt to stay ahead of the competition, companies have been pursuing strategies aimed at the creation of competitive advantages through cost-effectiveness and productivity improvements, quality improvements, customer service, and speed and responsiveness. These competitive responses have been brought to the fore by the total quality movement, the need for business process re-engineering (Hammer \& Champy, 1993) and the importance of time-based competition (Stalk, 1988). However, as Galbraith, Lawler \& Associates (1993) point out, productivity, quality, customer service and speed are becoming competitive necessities rather than sources of competitive advantage. In the business environment of the 1990 s, these abilities have to be developed and maintained - not to compete, but in order to survive.

The effects of the above strategic imperatives on the structure of organizations have been a general tendency towards downsizing, delayering (the elimination of hierarchical levels), staff reduction, and the creation of mechanisms for cross-functional co-ordination in order to ensure flexibility and adaptability. Companies are increasingly adopting a zerobased approach in evaluating the need for the range of functions that are provided internally. Outsourcing and sub-contracting are becoming substitutes for self-sufficiency in a competitive environment where companies have to be worldclass at everything they do. Since very few companies can be good at everything, the internal focus has shifted towards an emphasis on core competencies and capabilities (Prahalad \& Hamel, 1990). This has been true in particular with regard to staff functions, where more and more companies are starting to require their staff units to demonstrate the value that they can add to the business (Galbraith, Lawler \& Associates, 1993). Instrumental in this regard has been the focus on overhead cost elements highlighted by the new activity-based costing systems (Cooper \& Kaplan, 1991).

Another factor which have had an impact on organizational forms has been the shift towards buyers markets with customers continuously requiring new products and services (often customized), and demanding close relationships with suppliers. This increased penetration of the customer into the organization (often at lower levels), requires the decentralization of decision-making power and the internal differentiation of organizations on the basis of customer segments and products. Companies are under constant pressure to innovate and to get their new products or services to the market as quickly as possible. This requires high investments in research and development and in new technologies, which have 
forced companies to search for global markets in order to cover the costs of these fixed investments.

However, in the global arena, Western corporations have met competitors from Japan and from the new industrialized countries such as Singapore, South Korea and Taiwan, who play according to different rules. These competitors belong to societies that are organized on a very different basis than Western societies. Business in East Asia tends to be deeply intertwined with the social structure of families, communities and regions, and this, paradoxically, provides more opportunities for the creation of alternative organizational arrangements to confront competition. Only some regions in Italy, such as the Prato and the Sassuolo, and the notorious Silicon Valley in California, have been posed as Western equivalents of the embeddedness of economy and society that is encountered in East Asia. The nature of competition emanating from the East and the current trade imbalances that exist between East and West are putting pressure on Western corporations to imitate the structural arrangements of Eastern companies, to create Western keiretsu (the Japanese banking groups) and to find ways around antitrust laws (Galbraith et al., 1993).

The combined effect of the above forces has been the emergence of the new organizational forms which are found scattered throughout contemporary organizational literature. These include the lateral, the horizontal, the flat, the upsidedown or inverted, the flexible, the modular and the virtual organizations. Apart from these, various metaphors such as the 'starbust' and 'spiders web' organization (Quinn, 1992) and the 'shamrock' organization (Handy, 1990) have been proposed to signify underlying structural arrangements. Although there are some differences between these forms, most are mere synonyms for the same structural tendency. Furthermore, these forms are not new. They are all manifestations of what Burns \& Stalker (1961) referred to, already many years ago, as organic structures, and Galbraith (1973) as the lateral organization.

Whilst the forces discussed in this section have made structural change and adaptation necessary, two developments have made it possible. Firstly, the phenomenal growth in the development and application of new information technology has made the integration of loosely coupled organizational units possible. It has reduced the need for tall hierarchies, enabled the substitution of automated control for supervision (Zuboff, 1988), and facilitated the global dispersion and fragmentation of corporations, thereby giving rise to what Galbraith et al. (1993) refer to as location free organization structures. Secondly, and linked to the first, has been the shift towards competition on the basis of knowledge and skills. This has led to a change in the nature of the work force (in terms of skill levels) and, as a result, to a change in the nature of organizational control. Coupled with the need for decisionmaking close to the action, the recognition of the need for employee involvement at all levels in the organization, and the increased use of cross-functional and self-managing teams, self-control, peer-control and customer-control are being substituted for formal bureaucratic or supervisory control (Galbraith et al., 1993). Furthermore, performance measurement and reward systems have started to become output- and skillbased, rather than input- and task-based (Lawler, 1990).
It is, however, not only structural elements that are affected by these developments. Significant adjustments are also required to that which constitutes the managerial task, and to the professional identity, skills, knowledge, behaviour and values of executives (Roure et al., 1993). With the changing nature of organizational control, the traditional 'positional' sources of managerial power and authority lose their legitimacy. The shift towards flat organizational hierarchies and the use of cross-functional teams, necessitate the delegation of decision-making power. In these structures, authority is distributed and generally resides with the person or team who has the critical skills to perform a particular task or function. Managers, therefore, need to learn how to operate with little support from formal authority, and to adapt to the new roles of facilitator, coach and supporter, rather than decision-maker and supervisor. Furthermore, they need to develop the skills to establish and maintain the appropriate level of creative tension in their organizations, necessary for continuous learning and innovation (Senge, 1990).

Thus, the changing competitive landscape and the driving forces behind the imperative for structural adaptation, have forced managers all over the world to radically rethink their traditional ways of structuring, managing and governing firms. Whilst the environmental demands behind the above changes have not abated, and are likely to intensify even further, the transition from the relatively prosperous 1980 s to the economic crisis of the early 1990s has added impetus to the experimentation with new ways of organizational structuring. Indeed, companies are increasingly realizing that organization form matters (Williamson, 1985: 274) and that ultimately, there may be no long-term sustainable advantage except the ability to organize and manage (Galbraith et al., 1993: 3).

\section{Network organization}

We propose that the 'network organization' can be regarded as the underlying structural arrangement behind most of the new organizational alternatives that have emerged over the last decade or more. The term 'network organization' can however be applied to various phenomena and at different levels of analysis. A clear delineation of these levels and phenomena is not an easy task, not only because of the proliferation of the 'network' concept, but also because 'network organizations', by their very nature, are changing, elusive and transitory types of social arrangements. Nevertheless, we believe that the classification shown in Table 1, which forms the basis for the remainder of the article, provides a useful framework for conceptualizing the application of the network organization.

Table 1 Different meanings of network organizations

\begin{tabular}{|c|c|}
\hline Level of analysis & Content \\
\hline Economic/business systems & $\begin{array}{l}\text { Networks as social building blocks of a } \\
\text { country's business and economic fabric }\end{array}$ \\
\hline Inter-organizational networks & Constellations of laterallylinked firms \\
\hline Intra-organizational networks & $\begin{array}{l}\text { Non-bureaucratic, loosely coupled organiza- } \\
\text { tions }\end{array}$ \\
\hline Informal networks & $\begin{array}{l}\text { Informal organizational realities, critical to } \\
\text { get things done }\end{array}$ \\
\hline
\end{tabular}


Firstly, the application of the network concept will be considered at the macro socio-economic level, where social, economic and political units are linked to form closely integrated business systems such as those found in East Asia. At the second level, the network concept will be applied to the formation of collaborative lateral agreements between independent organizations within and across industries. These mutually beneficial agreements, which result from the relaxation of the traditional notion of self-sufficiency, are established not only with suppliers and customers, but also with competitors, and has led to the creation of a truly new social structure of competition. The resultant constellations of firms connected by such agreements, will be referred to as 'inter-organizational' or 'external networks'. Thirdly, the level of analysis will shift to the internal structuring of organizations, where the processes of delayering, hierarchical flattening and cross-functional integration will be discussed in terms of 'intraorganizational' or 'internal' networks. Finally, the article will address the informal organization or the spontaneous social systems within organizations, which will be referred to as 'informal' networks.

\section{Social networks as the structural foundation of business systems}

In a study of the competitive advantages of ten industrialized nations, Porter (1990) found that more than resource endowments, factors such as the creation of prosperity through continuous innovation and the presence of a challenging, dynamic and forward-looking home environment characterized by, inter alia, demanding customers and the presence of supporting industry clusters, are amongst the crucial determinants of national competitive advantage. The intriguing question emanating from this study is how recently industrialized countries such as Singapore and South Korea (included in Porter's ten nation sample) managed to become main players in the global competitive arena in such a relatively short period of time. The fact that the thriving Asian version of capitalism, exemplified by the economies of Japan, South Korea, Taiwan and Singapore, is based upon contrasting social and institutional principles compared to Western economies, has led scholars to acknowledge not only that capitalism comes in different forms, but also that, possibly, some of the fundamental underpinnings of Western economic and organizational practices should be reviewed.

If there is a common denominator of the Asian version of capitalist economies, it is the close interconnection that exists between economy and society - the reliance for organizational and economic functioning upon dense social networks. This is contrary to traditional Western thinking. In this regard, it may suffice to recall the famous statement by Weber (1968) that capitalism will function better, the more are absent from it human and social sentiments such as love, hate and jealousy. In the field of economics, this is portrayed in its dominant paradigm, neoclassical economics, which is based firstly on the notion of homo oeconomicus, a rational, non-emotive, profit-seeking individual, and secondly on a perspective of competition as being sustained between autonomous economic actors who, whether individual capitalists or firms, behave as if they are fictional, non-socialized personas (Granovetter, 1985).
Additional analysis may provide a better understanding of the particular social fabric of East Asian business systems. Whitley $(1992 \mathrm{a} ; 1992 \mathrm{~b})$ identifies the institutional variables that account for the differences between business systems. He distinguishes between 'background social institutions' and 'proximate social institutions'. Background social institutions usually originate in the pre-industrial political system and its legitimating principles, the traditional elite attitudes towards privately controlled concentrations of wealth, and the organization and control of agricultural activities.

According to Whitley, six background social characteristics prompt the development of business systems or, in terms of organizational economics, market-hierarchy configurations. The first characteristic is the basis for and degree of trust between non-kin. Trust, defined by Sabel (1993) as the mutual confidence that no party to an exchange will exploit the others vulnerability, is a critical component because it reduces transaction costs associated with the detailed specification of contracts and the possibility of post-contractual opportunistic behaviour. The second background feature is the commitment and loyalty to collectives beyond the family, crucial for the establishment of internal organizational hierarchies. The third factor proposed by Whitley, the importance of individual identities, rights and commitments, refers to the degree to which individuals with their rights, such as inalienable property rights, are considered as separate social units with distinct capabilities, skills and wants, not subordinated to the claims of aggregate social groups. The relevance of this point stems from the fact that where the legitimacy of collective claims and goals is subordinated to those of individuals, organizations will tend to be more formalized and bureaucratic and market transactions more based on formal, well-specified contracts. The final three background characteristics are closely interrelated. The fourth characteristic is the depersonalization and formalization of authority relationships. Highly personal forms of power and unspecified dependency relationships restrict the development of large, formally co-ordinated enterprises. The fifth factor refers to the differentiation of authority roles, and the sixth to the reciprocity, distance and scope of authority relationships.

While the six institutional background factors are of a social and cultural kind and, therefore, highly inertial and permanent, the 'proximate social institutions' that Whitley describes are much more dependent on recent historical developments, and therefore more subject to change. The characteristics of these institutions are: business dependence on a strong and cohesive state; state commitment to industrial development and risk sharing; capital market or credit-based financial systems; unitary or dual education and training systems; strong skill-based unions; and the public certification of skills and professional expertise.

In each society, the interplay between background and proximate institutions leads to the configuration of business systems with different characteristics. Researchers (Whitley, 1992a; Hamilton \& Biggart, 1988) have found in East Asia important variants between the three main business systems of the region. First, in Japan, the Kaisha or specialized clan exists via a separation of the permanent or core members of an organization from temporary workers, thus building high levels of mutual trust and commitment in the first group. 
Second, the South-Korean Chaebol is characterized by the hegemony of large conglomerates dominated by influential families. The third variant is the Chinese family business systems that are found in Taiwan and Hong Kong. Although these business systems differ along several dimensions, such as relevant economic actors, market organization, employment and personnel practices, and authority and control systems, there are some salient similarities, especially when contrasted with Western business or economic systems. The most important contrast is between the dominant model assumed in the West by neoclassical economics and most of organization theory (business systems dominated by selfsufficient actors, often organized as large formal bureaucracies, who interact in mainly anonymous markets), and the common basis of business systems in East Asia, where economic actors are more specialized and dependent on quasicontractual particularistic attachments. These are often manifested in dense networks of inter-personal and inter-organizational alliances, where dues and rights are socially enforced.

Apart form the eminently sociological perspectives of Whitley (1992) and Hamilton \& Biggart (1988), other approaches have also served to highlight the plurality of the institutional structures of economic and business systems. From a transaction cost perspective, Ouchi (1980), building on the distinction between markets and hierarchies proposed by Williamson (1975), argues that whereas hierarchies (or bureaucracies) replace markets as co-ordinating mechanism when transactions become moderately uncertain and complex, clans replace hierarchies when these uncertainties and complexities become excessive. The clan form of organization, which is based to a large degree on Japanese management practices, is characterized by shared values and goals, strong feelings of solidarity, implicit control mechanisms, and longterm employment. Boisot \& Child (1988) and Boisot (1994) extend this analysis and pay special attention to the processes by which economic knowledge, information and news are scanned, diffused and adopted. They add a fourth co-ordinating mechanism, the fief, to the three identified above and discriminate between these on the basis of information codification (see Table 2). Contrasting neoclassical economics with Schumpeterian economics, they note that the former has neither the theoretical focus nor the methodological tools to grasp this institutional diversity. Furthermore, they assert that networks, the way in which collective action is structured within the clan mode, allow for an economic guidance to be exercised at the industry or regional level that is higher than in market economies, yet lower than in centralized, planned economies. This gives rise to a new type of competition, in fact a new capitalism, based on organizational networks and social clans rather than markets.

To sum up this section, the success of East Asian economies has alerted scholars and practitioners in the West to two main considerations. Firstly, a high-performance capitalist system based on a social fabric of networks rather than markets or bureaucracies has emerged. In East Asia, networks of people and economic units, connected through differentially categorized social relationships and institutionalized in business and economic practices, form the basic building blocks of social order. Although culture contributes to the functioning of these networks, they are not culturally determined.
Table 2 Institutional alternatives of economic organization



Source: Boisot (1986)

The economic vitality of certain industrial regions in Italy and the United States has demonstrated that such territorial social organizations based on networks are also possible in the West. Secondly, the success and growth of the economies in the East have highlighted the cultural and societal contingencies of some of the most fundamental assumptions behind neoclassical economics, in particular the tenet of rational economic actors operating autonomously in an impersonal market.

If, as the networks of East Asian economies illustrate, there is a continuum of social and economic structures that goes from society to individuals, passing through communities, organizations and families, it is clear that inter- or intra-organizational networks cannot survive in a social environment that is void of the strong personal relationships necessary for social co-operation, collective trust and loyalty. Although the social fabric is stronger in the East, there is no doubt room in Western societies for the development of organizational structures that rely more on social ties and less on formalized rules for successful integration. Structures that depend more on collaborative agreements and less on competitive dynamics. Networks as organizational alternatives to markets and hierarchies are discussed in the following section.

\section{Inter- and intra-organizational networks}

In terms of the internal structuring of organizations, the driving forces behind structural change and adaptation have given rise to two related tendencies, the manifestations of which allow for two applications of the network concept to organizations. The fact that these tendencies often appear 
simultaneously and in the same organizations has been one of the main causes for the elusiveness of the concept 'network organization', which is sometimes used to refer to either one of the two, and sometimes to both.

The first tendency has been delayering, the breaking down of hierarchies and internal barriers between functional areas, decentralization of decision-making authority, the increased use of cross-functional and self-managing teams, greater emphasis on employee involvement, and an attempt to use market-oriented mechanisms to co-ordinate and horizontally link the activities of semi-autonomous business units. We shall use the term 'intra-organizational network' to represent the structural consequences of the above actions.

The second tendency has been the realization that while in today's competitive environment, companies cannot be 'world-class' at everything they do, they nevertheless cannot afford not to do everything well. This has led to a relaxation of the traditional notion of self-sufficiency, that is the tendency to make use of the collective assets of several firms generally located at different points along the value chain, often accompanied by a reduction in scale as well as scope of operations, through the opening up of organizational boundaries in order to establish mutually beneficial collaborative relationships not only with suppliers and customers, but also with competitors. These relationships, which include informal working agreements, equity partnerships, strategic alliances, joint ventures, technology licensing, and co-operative agreements in research and development, manufacturing, marketing and distribution, can vary from relatively permanent to highly transitory arrangements. The relational structures that emanate from this tendency will be referred to as 'inter-organizational networks'.

Many scholars have tried to advance a serics of characteristics common to both types of 'network organization' (intra and inter) or to identify the main dimensions along which they operate. Unfortunately, from an application point of view, most of these attempts have been formulated in the abstract and general language of organizational economics. Jones \& Hesterly (1993), for example, have proposed that 'network organizations' are relationship-based systems of repeated, idiosyncratic or mixed-idiosyncratic exchanges among autonomous units or firms producing goods and services. 'Relationship-based' implies that rather than comprehensive formal rules, standards and procedures (bureaucratic control) or impersonal price mechanisms (market control), social control (reputation and trust) is used as the main mechanism to enforce agreements and to govern exchanges. Such reputation and trust can only be established through a continuity of social relations, where information about past behaviour and incentives for future behaviour provide the basis for continuance, and through intensive socialization based on shared values and norms. Thus, the expression 'idiosyncratic or mixed-idiosyncratic exchanges'. Finally, the authors imply that these exchanges (between organizational units or between autonomous firms) are sustained not for the maintenance of an expressive relationship, but for instrumental economic purposes.

A further attempt at clarifying the concept 'network organization' is provided by Baker (1992). Apart from emphasizing the importance of informal organizational networks (to be considered in the following section) and the general aim of network structures to achieve the highest possible levels of flexibility, decentralized planning and control, and lateral (as opposed to vertical) ties, Baker proposes that the main structural characteristic of network organizations is the high degree of informal integration (vertically, horizontally and spatially) across formal boundaries. In other words, in classic sociological terms, network organizations maintain cohesiveness through organic rather than mechanistic solidarity, which makes them resemble communities rather than societies. Informal structures, therefore, constitute the essence of organization on the basis of networks.

Along similar lines, Miles \& Snow (1992) offer four characteristics of network organizations (applicable to intra- and inter-organizational networks as well as to social networks in general) which distinguish them from previous organizational forms. The first characteristic is what we have termed the relaxation of the need for self-suffiency. The second point is the greater reliance on market mechanisms for managing resource flows. The third characteristic refers to expectations regarding relationships that go beyond the mere compliance with formal obligations. Finally, the authors see the network organization evolving towards an organizational collective, similar to the Japanese keiretsu, based on mutual share holding and co-operation.

Given the above, network organizations are neither pure bureaucracies (since collaboration takes place mainly through informal structures and social relations), nor pure markets (since elements of internal co-ordination and control are still retained). Rather, intra- and inter-organizational networks can be regarded as organizations that are located somewhere between these two extremes, sharing characteristics of both, partially open to the environment and partially formalized internally. We believe that, from a conceptual point of view, the distinction between intra- and inter-organizational networks is useful. However, this may be less so from a practical point of view, since the dynamics of the structure and governance of intra-organizational networks often demand the establishment of inter-organizational networks and vice versa.

Nevertheless, as a pure 'type', the intra-organizational network, or the 'internal network' (Snow, Miles \& Coleman, 1992), can be viewed as an organizational structure where commonly owned business units operate quite autonomously without much outsourcing. Scarce resources are allocated along the value chain using market mechanisms, with the purpose of obtaining competitive advantage through this shared asset utilization. The contemporary multinational corporation (MNC) can be viewed as one example of an intra-organizational network (Ghoshal \& Bartlett, 1990). It generally consists of a group of spatially dispersed and often goal-disparate units embedded in a constellation of other organizations, such as customers, suppliers, competitors and regulators, and thus exhibits the basic structural properties of intra-organizational networks: a high degree of differentiation and decentralization, coupled with the corresponding need for integration, which is obtained through a combination of bureaucratic and market-oriented mechanisms.

It is possible to extend this analysis of intra-organizational networks by visualizing a continuum of progressively increasing network complexity as the level at which the 
network structure becomes operational shifts from the business unit level, to the level of interacting teams, across unit boundaries, and finally to the level of individuals who may link up temporarily at any point in time with different crossunit and cross-functional teams in order to address particular problems, only to disband (or for the time being, severe) these linkages in order to form new ones for the next problem set. In the latter situation, often found in the dense and highly complex interpersonal networks of professional firms and high-performance companies, structure becomes very much a dependent variable to be likened more with 'nomadic tentpitching' than with 'castle building'.

Moving from the intra-organizational network to the interorganizational network entails a step closer to the market side of the market-bureaucracy continuum. Again, as a pure 'type', the inter-organizational network can be viewed as a collection of independent (often single-function) companies closely linked to a network 'integrator' (Galbraith et al., 1993), which outsources a substantial part or even all of its input and output functions to these companies. Assets and risk are therefore distributed amongst a number of independent firms, all more or less dedicated to a particular value chain.

Depending on the temporal stability of network relationships, the role of the network integrator can be either that of a 'core' firm or a 'broker', giving rise to what Snow et al. (1992) refer to as 'stable' and 'dynamic' networks respectively. As the 'core' firm, the network integrator typically performs the dominant function(s) in the value chain and outsources the less proprietary tasks. Influence over the independent companies in the network is obtained through the building of relationships based on trust and mutual interest, and by developing a power base through the provision of centralized buying, selling and other services. Where network relationships are more fluid and dynamic, the role of the network integrator can be likened to that of a 'broker' who temporarily links and packages, for a particular project or product, the assets owned by other independent companies. When completed, the network is decoupled and a new one formed (possibly with different members in different configurations) for the next venture.

The fact that inter-organizational networks are aimed at providing firms with the necessary flexibility to respond quickly to the changing and heterogeneous demands of the market place, does not mean that they are inherently unstable or fixated merely on short-term tactical considerations. Various researchers (see for example Jarillo, 1988; 1993; and Nohria \& García-Pont, 1991) have stressed the strategic consequences of inter-organizational networks which, within a given industry, may give rise to different strategic blocks, often formed across strategic groups (Caves \& Porter, 1977). A strategic block represents the pool of strategic resources and capabilities to which a particular firm may have access. For instance, in the automobile industry, Nohria \& García-Pont (1991) discovered two types of strategic blocks: 'complementary blocks', composed of firms with very different strategic capabilities (which for a particular firm may be interpreted as an attempt to obtain scope economies); and 'pooling blocks', composed of firms with similar strategic capabilities (which can be interpreted as an attempt to obtain scale economies).
Strategic linkages in inter-organizational networks may provide firms with several benefits. Firstly, by establishing linkages with companies possessing complementary resources and capabilities, a firm can gain access to these capabilities without having to incur the costs associated with selfsufficiency and dilute the focus of capital deployment. Secondly, a firm can obtain increased market power from its already available capabilities by pooling resources with other companies. In both cases, these linkages may also provide the opportunity to learn new capabilities, assist in the reduction of environmental uncertainty, and offer the means for faster repositioning as possible through internal development.

However, as Nohria \& García-Pont (1991) also suggest, performance differences between firms and strategic blocks do not arise only from superior access to strategic capabilities, but also from the ability to manage inter-organizational networks. Since network organizations are relatively 'thin' in formal structure but 'thick' in social and informal relations, managing such organizations requires a clear understanding of the internal, informal networks (present in and important to all organizations) in which these relations are embedded.

\section{Informal networks}

In their well-known study of the matrix organization, Davis \& Lawrence (1977) state that a matrix organization entails more than merely a matrix structure. Also required are matrix systems, a matrix culture and matrix behaviour. Similarly, we could say that network organizations are not just structures exhibiting open, loose, cross-functional and boundary-spanning relations, but also require network systems, a network culture and network behaviour which, to a large degree, depend on the efficacy of the informal organization. In fact, a network organization is by definition the 'structural' acknowledgment and realization that it is through the informal organization that power or influence is exercised, trust built, support delivered, and non-routine knowledge spread. That is, an acknowledgment that the way to get things done in organizations is mostly through the thick and dense informal networks present in all of them. In the network organization we find a fusion between the formal and the informal, with the latter becoming the model on which the whole organization structure is built.

While conscious attention to network organizations is rather recent, the acknowledgment of the importance of the so-called informal organization is not new, nor peculiar to networks. The first stage of academic thought on management and organizations, the so-called scientific management school, was fixated with the characteristics of efficient bureaucracies, which were conceptualized in mere structural terms. As Warren Bennis (1959) said, these were organizations without people. It was partly in response to the limitations of this approach, that the second phase in the development of organization theory, a tradition which was started in the 1930s at the Harvard Business School, was marked by an explicit focus on the human or people side of organizations and, in particular, the informal organization. The scholars who contributed to this tradition (amongst others, Mayo, 1945; Roethlisberger, 1977; and Homans, 1951) all realized, as Scott (1992) states, that individuals in organizations are never merely hired hands, but bring with 
them their heads and hearts: they enter the organization with individually shaped ideas, expectations and agendas, and they bring with them differing values, interests and abilities. Furthermore, these organizational members, apart from performing the officially prescribed tasks, enter into social relationships with one another, not only for expressive reasons such as shared values and the need for friendship and camaraderie, but also for instrumental ones such as obtaining mutual support for furthering interests and agendas. These social relations, which exhibit the properties of stability, recurrence, idiosyncrasy and the like, form the informal networks.

The existence of informal relationships in organizations also did not escape the attention of sociologists. Several decades ago, Moreno developed sociograms to represent smallscale interpersonal configurations such as those that take place in classrooms. However, it was only in the 1960 s that sociologists like Rapoport, Coleman, White and their disciples were able to develop a quantitative methodology capable of tracing network relationships in larger settings, such as corporations (see for example Coleman, 1964). Today, network theory has become one of the booming fields in sociology.

Since informal networks reveal the hidden but real organizations behind the corporate charts (the way work gets done in the 'white spaces' of these charts), the benefits that managers may obtain from internal network analysis will primarily come from an understanding of the dynamics of power and influence in the work place. This, of course, is crucial from a managerial action point of view. As we have seen earlier, the delayering or flattening of organizational structures coupled with the opening up of organizational boundaries, lead to a reduction in the legitimacy of the 'traditional' positional sources of managerial power and to a concomitant adjustment in the very notion of what constitutes the managerial task. More than ever before, managers need to develop their political skills and networking abilities in order to deal with other significant actors, both in internal as well as external networks, over whom they have little if any formal authority.

Krackhardt \& Hanson (1993) identify three basic types of informal networks that managers should take account of. The first is the 'advice network' which reveals the actors on whom others depend to get information and to solve problems. This network may also be used to identify sources of internal political conflicts and the reasons for hold-ups in strategy implementation. The second type of network, the 'trust network', identifies the employees who share sensitive political information and who back one another in political confrontations, and can be used to reveal the causes of nonroutine organizational problems. Finally, the 'communications network' provides information on the organization members who interact frequently on work-related matters. An analysis of this network may be used to uncover possible gaps in the flow of information in the organization which may contribute to the inefficient use of available resources.

Since it is through the informal organization and its constituent networks that much of what goes on in organizations gets done, managers should concern themselves not only with aligning strategy wich formal structure, processes and systems, but also with the political and social realities of the organization (Ibarra, 1991; 1993). They have to develop the ability to assess the consequences of strategic and structural changes on the informal network. In their article, Krackhardt \& Hanson (1993) enumerate five basic configurations that, if present in organizations, should lead managers to carefully reconsider the 'fit' of the informal organization with company goals and strategies. The first is what they call 'imploded re. lationships', where an analysis of the communication network reveals that an organizational unit has few direct links with other groups at the same level, instead depending on higher organizational levels for these linkages. The second and opposite configuration, 'irregular communication' patterns, arises when members of a group communicate more with outside members than with one another, which may indicate the presence of group anomie and lack of cohesion. 'Fragile structures' occur when strong networks of advice, trust and communication are limited to some parts of the organization. An extreme case would be the presence of 'network holes', when a network map shows no relationships between units that should have developed them in order for the organization to function. The last configuration mentioned by the authors is what they call the presence of 'bow ties', where many organizational members depend on one powerful actor rather than on each other.

To sum up, experienced managers have always realized the importance of the informal realities of organizations, especially from a political point of view. However, the radical structural adaptations that many companies are experiencing in response to changing environmental demands, add urgency to the need for managers to develop network analysis and intervention skills. As Krackhardt \& Hanson (1993: 111) point out: 'understanding relationships will be the key to managerial success'.

\section{Conclusion}

Network theory has had a great impact on academic and applied management literature. In this article, we have tried to disentangle the different meanings of the concept 'network organization'. The concept has two basic meanings that usually co-exist in organizational realities. First, intra-organizational networks refer to those organizations that have abandoned highly hierarchical structures in favour of loose, flat and adaptive constellations of market-oriented semiautonomous units. Second, inter-organizational networks refer to the opening up of organizational boundaries in order to establish collaborative agreements with other organizations in an attempt to ensure 'world-class' performance in all activities. In addition, we have made reference to the business systems of East Asia, organized on the basis of a macro social network structure, whose existence and success to date could help us consider alternatives to the individual-oriented social and economic configurations of the Western capitalist system. Finally, we have discussed the notion of informal networks, present in all organizations, that has provided scholars with insights into the functioning and governance of all kinds of formal organizational networks.

The network organization has been referred to as 'the organization of the future' (Snow et al., 1992). Although somewhat elusive and applicable to different levels of analysis, we have presented it as the underlying structural arrangement behind most of the recent developments in organizational forms, 
and as such as an alternative to bureaucracy - the structural form that has dominated organizational life in the twentieth century.

Max Weber (1968), many years ago, described the bureaucracy as an organization with the following characteristics: clearly specified jurisdictional areas; hierarchical control; comprehensive rules governing official decisions and actions; a clear separation of personal and official property and rights; personnel selection on the basis of technical qualifications; and a view of employment as constituting a life-long career. In contrast (and revealingly), network organizations share many features with the pre-capitalist organizations, based on charismatic or traditional authority, that bureaucracies came to substitute: division of labour is not rigid and assignments (often temporary) are mostly made by the leader and based on skills; authority relations are diffused, more dependent on personal loyalty and trust and not ordered according to clear hierarchies; general rules of administration either do not exist or are vaguely stated; there is no clear separation of the leader's personal 'household' business from the larger 'public' business; and lastly, selection of organizational members are made on the basis of particularistic criteria (there is no security of tenure).

As we have stated before, the 'network organization' is not something new. It is a direct descendant of concepts such as the 'lateral' organization (Galbraith, 1973) and before that, the 'organic' form (Burns \& Stalker, 1961) which in turn has been drawn from the traditional sociological concepts of organic as opposed to mechanistic solidarity and community as opposed to society, both determinants of pre-capitalist social structures. The network organization, therefore, contains some pre-modern traits (as discussed above) mixed with postmodern characteristics, such as fluidity, adaptability and an in-built skepticism towards stable and formal structural arrangements. However, it will also continue to exhibit, albeit in modified form, some of the typical modern characteristics associated with bureaucracy, such as hierarchy. Wherever organized activity takes place, some form of hierarchy is bound to exist, if only consisting of two levels. Hierarchy (or for that matter bureaucracy) is here to stay; it is, as Eccles \& Nohria (1992: 133) put it, 'the legacy of people's ongoing attempts to build their identities and achieve control in their environments'.

There has always been a plurality of organizational forms in modern economies, with the main divide being between small and large firms. While the latter have been based primarily on the bureaucratic form, small firms (the remnants of pre-modern capitalism) have always been organized around the personality of their owners or managers. The idiosyncratic needs of these firms have generally been less amenable to the normative proposals of academics and consultants. With the coming of the network organization, however, the distinction between small and large firms is likely to become blurred, at least to some extent. As Miles \& Snow (1986) assert, the network organization '... permits a company to be large when it is advantageous to be large and small when it is good to be small'.

In the future, we should expect a more varied repertoire of organizational forms, both 'ideal' (if only temporarily) and 'real'. The success of the network organization in all its guises, the proliferation of small firms, and the persistence of large bureaucracies, will provide us with a broader collection of suitable organizational models than what has been available in the last half century, when the bureaucratic model was widely hegemonic. Although the network organization will not be the only organizational form of the future, it is likely to be one of the most frequently adopted by companies in their attempt to respond to the changing demands of the market place.

However, as Miles \& Snow (1992) warn us, all the prior organizational forms have met with initial widespread success, only to be followed by a growing list of failures. They argue that these failures have arisen from two types of subtle managerial 'mistakes', also applicable to the network organization: the apparently logical extension of the form beyond the limits of its capability, and the inappropriate modification of the form, leading to a violation of its operating logic. Managers should not only heed this warning but also take note of the advice offered by Eccles \& Nohria (1992) who urge that structure should be seen as a malleable tool to solve problems and to get things done. The authors state (1992: 134): ‘... unfortunately, our natural tendency is to think of structure in more architectural terms, as something like a building that one can simply fill and empty of people at will'. Yet, structure goes much beyond that. It is constantly shaped and changed by the actions of the people who occupy it, and therefore should be designed around and for them.

We have highlighted the many advantages associated with the network organization. But, apart from its structural and behavioural consequences, we should also recognize the value of network thinking. By perceiving their organizations in network terms (whether organized accordingly or not), managers will develop the ability to look beyond the obvious formal structure and to define their organizations in a broader social context or, as Pfeffer (1987) puts it, to bring the environment back in. It will encourage a focus on relationships not only the important, dense linkages, but also the peripheral ones which may, at times, be crucial. In other words, it will help managers to distinguish the 'figure' from the 'ground', while at the same time alert them not to forget about the 'ground' (Perrow, 1986: 206).

Finally, we expect the proliferation of network organizations to stimulate management scholars, consultants, entrepreneurs and managers to think not only about new alternatives for improving organizational flexibility and responsiveness, but also about new and creative ways of managing them. After many fads and hype, managing change, in all its terminological disguises, is becoming one of the most valuable managerial skills. The application of this skill for structuring and governing innovative economic activities, is likely to depend more and more on the flexibility and changeability offered by the network organization. In addition, its built-in accessibility to different and varying configurations, and its malleability through executive action or intervention, should assist managers in learning and developing new managerial skills, cognitive maps, and interpersonal habits, personally more rewarding and organizationally more effective than those facilitated by the more rigid, traditional bureaucratic organization. The following quote captures the possibilities for 
managerial development that are being opened up by the network organization:

'The good manager can function effectively only in an environment of continual change ... Only with many changes in the works can the manager discover new combinations of opportunities and open up new corridors of comparative indifference ... In the day-to-day operation of a going concern, they find the milieu to maneuver and conceptualize' (Wrapp in Hamermesh, 1983: 491,496 - as quoted in turn by White, 1992: 273).

\section{Acknowledgement}

The authors would like to thank Joan E. Ricart of IESE and José M. Anzizu of the Centre for Organizational Studies for helpful comments on earlier drafts of this article. The financial assistance of the Centre for Science Development, HSRC, South Africa, towards this research is acknowledged. Opinions expressed and conclusions arrived at are those of the authors and are not necessarily to be attributed to the Centre for Science Development.

\section{References}

Baker, Wayne. 1992. 'The network organization in theory and practice'. In Nohria, Nitin \& Eccles, Robert G. (eds.). Networks and organizations: structure, form and action. Boston, MA.: Harvard Business School Press.

Barnard, Chester I. 1938. The functions of the executive. Cambridge, MA.: Harvard University Press.

Bennis, Warren G. 1959. 'Leadership theory and administrative behavior', Administrative Science Quarterly, Vol. 4: 259-301.

Boisot, Max \& Child, John. 1988. 'The iron law of fiefs: bureaucratic failure and the problem of governance in the Chinese system reforms', Administrative Science Quarterly, Vol. 33 (December): 507-527.

Boisot, Max (ed.). 1994. East-west business collaboration: the challenge of governance in post-socialist enterprises. London: Routledge \& COS.

Burns, Tom \& Stalker, George M. 1961. The management of innovation. London: Tavistock.

Burt, Ronald. 1992. Structural holes: the social structure of competition. Cambridge, MA.: Harvard University Press.

Business Week, December 20, 1993. 'The horizontal corporation'.

Caves, Richard E. \& Porter, Michael E. 1977. 'From entry barriers to mobility barriers: conjectural decisions and contrived deterrence to new competition', Quarterly Journal of Economics, Vol. 91 (May): 241-262.

Coleman, J. S. 1964. Introduction to mathematical sociology. New York: Free Press.

Cooper, Robin \& Kaplan, Robert S. 1991. 'Profit priorities from activity-based costing', Harvard Business Review , Vol. 69 (MayJune): 130-135.

Chandler, Alfred D. Jr. 1962. Strategy and structure. Cambridge, MA.: The MIT Press.

Davis, Stanley M. \& Lawrence, Paul R. 1977. Matrix. Reading, MA.: Addison-Wesley.

Eccles, Robert G. \& Nohria, Nitin (with James D. Berkley). 1992. Beyond the hype: rediscovering the essence of management. Boston, MA.: Harvard Business School Press.

Fayol, Henri. 1949. (Trans.). General and industrial management. London: Pitman (first published in 1916).

Galbraith, Jay R. 1973. Designing complex organizations. Reading, MA.: Addison-Wesley.
Galbraith, Jay R. 1987. 'Organization design'. In Lorsch, Jay (ed.). Handbook of organization behavior. Englewood Cliffs, NJ.: Prentice-Hall.

Galbraith, Jay R. \& Lawler, Edward E. III \& Associates. 1993. Or. ganizing for the future. San Francisco: Jossey-Bass Publishers.

Ghoshal, Sumantra \& Bartlett, Christopher A. 1990. 'The multinational corporation as an interorganizational network', Academy of Management Review, Vol. 15 (October): 603-625.

Granovetter, Mark. 1985. 'Economic action and social structure: the problem of embeddedness', American Journal of Sociology, Vol. 91 (November): 481-510.

Hamilton, Gary \& Biggart, Nicoles W. 1988. 'Market, culture and authority: a comparative analysis of management and organization in the Far East', American Journal of Sociology, Vol. 94 (Supplement).

Hammer, Michael \& Champy, James. Reengineering the corporation: a manifesto for business revolution. London: Nicolas Drealey Publishers.

Handy, Charles B. 1990. The age of unreason. Boston, MA.: Harvard Business School Press.

Hannan, Michael T. \& Freeman, John. 1989. Organizational ecology. Cambridge, MA.: Harvard University Press.

Homans, George C. 1951. The human group. New Brunswick, NJ.: Transaction Publishers.

Ibarra, Herminia. 1991. Structural alignments, individual strategies, and managerial action: elements toward a theory of getting things done in organizations. Working Paper, Harvard Business School.

Ibarra, Herminia. 1993. 'Network centrality, power, and innovation involvement: determinants of technical and administrative roles', Academy of Management Journal, Vol. 36, No. 3.

Jarillo, J. Carlos. 1988. 'On strategic networks', Strategic Management Journal, Vol. 9 (January-February): 31-41.

Jarillo, J. Carlos. 1993. Strategic networks: creating the borderless organization. Oxford, UK.: Butterworth-Heineman.

Jones, Candace \& Hesterly, William. 1993. A network organization: alternative governance form or a glorified market? Paper presented at the 1993 meeting of the American Academy of Management, Atlanta, Georgia.

Krackhardt, David \& Hanson, Jeffrey R. 1993. 'Informal networks: the company behind the chart', Harvard Business Review, Vol. 71 (July-August): 104-111.

Lawler, Edward E. III. 1990. Strategic pay: aligning organizational strategies and pay systems. San Francisco: Jossey-Bass Publishers.

Lawrence, Paul R. \& Lorsch, Jay W. 1967. Organization and environment. Boston: Graduate School of Business Administration, Harvard University.

Mayo, Elton. 1945. The social problems of an industrial civilization. Boston, MA.: Graduate School of Business Administration, Harvard University.

Miles, Raymond E. \& Snow, Charles C. 1986. 'Network organizations: new concepts for new forms', California Management Review, Vol. 28 (Spring): 62-73.

Miles, Raymond E. \& Snow, Charles C. 1992. 'Causes of failure in network organizations', California Management Review, Vol. 34 (Summer): 53-72.

Mintzberg, Henry. 1979. The structuring of organizations. Englewood Cliffs, NJ.: Prentice-Hall.

Nohria, Nitin \& García-Pont, Carlos. 1991. 'Global strategic linkages and industry structure', Strategic Management Journal, Vol. 12 (Summer - special issue): 105-124.

Nohria, Nitin. 1992. 'Is a network perspective a useful way of studying organizations?' In Nohria, Nitin \& Eccles, Robert G. (eds.). Networks and organizations: structure, form, and action. Boston, MA.: Harvard Business School Press.

Nohria, Nitin \& Eccles, Robert G. (eds.). 1992. Networks and orga- 
nizations: structure, form, and action. Boston, MA.: Harvard Business School Press.

Ouchi, William G. 1980. 'Markets, bureaucracies and clans', Administrative Science Quarterly, Vol. 25: 129-141.

Perrow, Charles. 1986. Complex organizations. New York: McGraw-Hill.

Peters, Thomas J. \& Waterman, Robert H. Jr. 1982. In search of excellence. New York: Harper and Row.

Pfeffer, Jeffrey. 1987. 'Bringing the environment back in: the social context of business strategy changing'. In Teece, David J. (ed.). The competitive challenge: strategies for industrial innovation and renewal. Cambridge, M.A.: Ballinger Publishing Company.

Porter, Michael E. 1990. The competetive advantage of nations. New York: Free Press.

Prahalad, C.K. \& Hamel, Gary. 1990. 'The core competence of the corporation', Harvard Business Review, Vol. 68 (May-June): 79 91.

Quinn, James B. 1992. Intelligent enterprise. New York: Free Press. Roethlisberger, Fritz J. 1977. The elusive phenomena. Cambridge, M.A.: Harvard University Press.

Roure, Juan, Alvarez, José Luis, García-Pont, Carlos \& Nueno, José. 1993. 'Managing internationally: international dimensions of the managerial task', European Management Journal, Vol. 11 (December): $485-492$.

Rumelt, Richard P. 1986. Strategy, structure, and economic performance. Boston, M.A.: Harvard Business School Press (first published in 1974).

Sabel, Charles. 1993. 'Studied trust: building new forms of coopera- tion in a volatile economy', Human Relations, Vol. 46, No. 9.

Scott, W. Richard. 1992. Organizations: rational, natural, and open systems. Englewood Cliffs, NJ.: Prentice-Hall.

Senge, Peter M. 1990. The fifth discipline: the art and practice of the learning organization. New York: Doubleday.

Snow, Charles C., Miles, Raymond E. \& Coleman, Henry J. Jr. 1992. 'Managing 21 st century network organizations', Organizational dynamics, Vol. 20 (Winter): 5-20.

Stalk, George. 1988. 'Time - the next source of competitive advantage', Harvard Business Review, Vol. 66 (July-August).

Taylor, Frederick W. 1911. The principles of scientific management. New York: Harper.

Weber, Max. 1968. (Trans.). Economy and society: an interpretative sociology. Edited by Roth, Guenther \& Wittich, Claus. New York: Bedminster Press (first published in 1924).

White, Harrison C. 1992. Identity and control: a structural theory of social action. Princeton, New Jersey: Princeton University Press.

Whitley, Richard. 1992a. Business systems in East Asia: firms, markets and societies. London: Sage.

Whitley, Richard. 1992b. European business systems: firms and markets in their national contexts. London: Sage.

Williamson, Oliver E. 1975. Markets and hierarchies: analysis and antitrust implications. New York: Free Press.

Williamson, Oliver E. 1985. The economic institutions of capitalism. New York: Free Press.

Zuboff, Shoshana. 1988. In the age of the smart machine: the future of work and power. New York: Basic Books. 